\title{
Alfalfa pellet-induced subacute ruminal acidosis in dairy cows increases bacterial endotoxin in the rumen without causing inflammation
}

\author{
E. Khafipour, D. O. Krause, and J. C. Plaizier ${ }^{1}$ \\ Department of Animal Science, University of Manitoba, Winnipeg, Manitoba, Canada R3T 2N2
}

\begin{abstract}
A study was conducted to determine if subacute ruminal acidosis (SARA) induced by feeding alfalfa pellets results in increases in free bacterial lipopolysaccharide (LPS) in rumen fluid and peripheral blood, and acute phase proteins in plasma, and to determine the effect of alfalfa pellet-induced SARA on feed intake, rumen fermentation characteristics, milk production and composition, and blood metabolites. Eight lactating Holstein cows, 4 of which were ruminally cannulated, were used in a 6-wk experiment and were fed once daily at $0900 \mathrm{~h}$. During wk 1, cows received a diet containing $50 \%$ of DM as concentrate and $50 \%$ of DM chopped alfalfa hay. Between wk 2 and wk 6 , alfalfa hay was gradually replaced with alfalfa pellets at the rate of $8 \%$ per week to reduce rumen $\mathrm{pH}$. $\mathrm{Ru}-$ men $\mathrm{pH}$ was monitored continuously in the ruminally cannulated cows using indwelling $\mathrm{pH}$ probes. Rumen fluid and peripheral blood were sampled 15 min before feed delivery and at $6 \mathrm{~h}$ after feed delivery. Based on adopted threshold of SARA of at least $180 \mathrm{~min} / \mathrm{d}$ below $\mathrm{pH}$ 5.6, SARA was induced from wk 3 onwards. Replacing $40 \%$ of alfalfa hay with alfalfa pellets quadratically increased the DMI from $18.1 \mathrm{~kg} / \mathrm{d}$ in wk 1 to $23.4 \mathrm{~kg} / \mathrm{d}$ in wk 6 . This replacement linearly decreased milk yield ( 32.7 vs. $35.9 \mathrm{~kg} / \mathrm{d}$ ) and milk fat percentage and yield ( 2.32 vs. $3.22 \%$, and 0.77 vs. $1.14 \mathrm{~kg} / \mathrm{d}$, respectively), but increased milk protein percentage and yield (3.80 vs. $3.04 \%$, and 1.23 vs. $1.07 \mathrm{~kg} / \mathrm{d}$, respectively). This gradual replacement also linearly increased the daily averages of total volatile fatty acids (90 to $121.9 \mathrm{mM}$ ), acetate (53.9 to $66.8 \mathrm{mM}$ ), propionate (21.5 to 39.6 $\mathrm{m} M$ ), and osmolality (277.7 to $293.8 \mathrm{mmol} / \mathrm{kg}$ ) in the rumen and decreased the acetate to propionate ratio from 2.62 to 1.73 . Replacing alfalfa hay with alfalfa pellets linearly increased blood lactate from $1.00 \mathrm{mM}$ in wk 1 to a peak of $3.46 \mathrm{~m} M$ in wk 5 . Induction of SARA in this study increased free rumen LPS concentration from 42,122 endotoxin unit $(\mathrm{EU}) / \mathrm{mL}$ in wk 1
\end{abstract}

Received August 26, 2008.

Accepted November 15, 2008.

${ }^{1}$ Corresponding author: plaizier@ms.umanitoba.ca to $145,593 \mathrm{EU} / \mathrm{mL}$ in wk 6 . However, this increase was not accompanied by an increase in LPS $(<0.05 \mathrm{EU} /$ $\mathrm{mL}$ ) and in acute phase proteins serum amyloid-A, haptoglobin, and LPS-binding protein in peripheral circulation. Results suggest that SARA induced by alfalfa pellets increased LPS in the rumen without causing translocation of LPS and an immune response.

Key words: subacute ruminal acidosis, lipopolysaccharide, acute phase response

\section{INTRODUCTION}

Current definition of subacute ruminal acidosis (SARA) and recommendations for its diagnosis in dairy herds are mainly based on rumen $\mathrm{pH}$ that is derived from the spot sampling of rumen fluid or with continuous rumen $\mathrm{pH}$ measurement (Garrett et al., 1999; Plaizier et al., 2008). To refine the definition of SARA based on rumen fluid collection, Gozho et al. (2005) suggested that free rumen LPS concentration be considered. Rumen $\mathrm{pH}$ depression during SARA increases free LPS concentration of the rumen (Gozho et al., 2007; Emmanuel et al., 2008) and this increase accompanies translocation of LPS from the gut into blood circulation, and activation of an inflammatory response (Khafipour et al., 2009). However, the correlation between decreased rumen $\mathrm{pH}$, increased LPS in the rumen, and increased acute phase proteins as inflammatory markers in blood have only been studied when SARA was experimentally induced by increasing the content of starch in the diet (Gozho et al., 2007; Emmanuel et al., 2008; Khafipour et al., 2009). Therefore, it cannot be concluded that the clinical signs, especially increase in inflammatory markers, that are associated with grain-induced SARA are caused by the increase in rumen acidity or by the high starch content of the diet.

Evidence in support of this view comes from studies looking at the site of LPS translocation into the blood. Although a recent in vitro study indicated that LPS translocates across the rumen and colon wall (Emmanuel et al., 2007), others believe that rumen epithelium has a low permeability to LPS as infusion of Cr-labeled LPS into the rumen of steers was not followed by LPS 
translocation into the thoracic duct (lymph) or portal vein (Lassman, 1980; Anderson, 1984). If LPS does not translocate into blood circulation from the rumen, then peripheral LPS during grain-induced SARA must be translocated through the epithelium of the small or large intestine. However, before arriving at these sites, free rumen LPS is detoxified in the duodenum, primarily by bile acids (Bertok, 1998). Therefore, free LPS in the lower gut must originate from the bacterial community of the terminal ileum and the large intestine. Grain-induced SARA may trigger the release of LPS from gram-negative bacteria in these components of gastrointestinal tract by increasing the amount of starch in the intestine. This may increase the luminal LPS concentration to the levels that impairs the barrier function of monolayer epithelium of the small and large intestine, and that may initiate the inflammatory reaction seen during grain-induced SARA.

Diets that are low in coarse fiber can reduce chewing activity, saliva production, and rumen buffering, and can result in rumen $\mathrm{pH}$ depression similar to graininduced SARA (Beauchemin et al., 2003). In particular, ground and pelleted forages could result in more rapid decline in rumen $\mathrm{pH}$, probably due to more rapid solubilization of non-cell-wall components (Daffaalla and Kay, 1980). In this study, we replaced chopped alfalfa hay with alfalfa pellets to induce low $\mathrm{pH}$ in the rumen without any changes in the starch content or in forageto-concentrate $(\mathbf{F}: \mathbf{C})$ ratio of the diets. The objectives of this study were to determine if SARA induced by feeding alfalfa pellets results in increases in free LPS in rumen fluid and peripheral blood, and if this method of SARA induction stimulates systemic inflammatory response. The effects of alfalfa pellet-induced SARA on feed intake, rumen fermentation characteristics, milk production and composition, and blood metabolites were also determined.

\section{MATERIALS AND METHODS}

\section{Animals, Diets, and Experimental Procedures}

Cows were housed in individual tie-stalls in Glenlea Dairy Research Station at the University of Manitoba (Winnipeg, Canada) in accordance with the guidelines of Canadian Council on Animal Care (CCAC, 1993). Eight dairy cows (175 \pm 75 DIM; mean \pm SD), four ruminally cannulated, were used in a 6 -wk study. Cows had an average milk yield of $35.9 \pm 5.4 \mathrm{~kg}$ and an average BW of $648 \pm 64 \mathrm{~kg}$ at the beginning and $649 \pm$ $53 \mathrm{~kg}$ at the end of the experiment. During wk 1, cows received a TMR that contained $50 \%$ of DM as concentrate and $50 \%$ of DM as chopped alfalfa hay (Tables 1 and 2). From wk 2 to wk 6, alfalfa hay was gradually replaced with alfalfa pellets at the rate of $8 \%$ per week (DM basis) to induce SARA (Table 1). Cows were fed once daily ad libitum with the intention of allowing for 5 to $10 \%$ orts and had free access to fresh water for the duration of the experiment. The health of animals was monitored daily by checking feed consumption and rumen $\mathrm{pH}$. In addition, body temperature and milk SCC were monitored weekly for clinical signs of inflammation and mastitis as these could affect LPS and acute phase proteins concentrations in blood. Weekly samples of diets, dietary ingredients, and orts were collected and analyzed by wet chemistry as described by Bhandari et al. (2007). The physical characteristics of alfalfa pellets, including dimension, bulk density, and water-holding capacity were determined as described by Giger-Reverdin (2000).

\section{Rumen pH Measurement}

Rumen $\mathrm{pH}$ was monitored continuously for 5 consecutive days during each week of experiment only in 4 ruminally cannulated cows using indwelling $\mathrm{pH}$ probes. The $\mathrm{pH}$ probes were placed in the ventral sac of the rumen, and their positions were checked twice a day at 0830 and $1630 \mathrm{~h}$. Rumen $\mathrm{pH}$ was measured at 1-min intervals and data stored in a data logger for subsequent analysis as described by Gozho et al. (2006). The pH data were summarized as average $\mathrm{pH}$, time spent below $\mathrm{pH}$ 6.0, time spent below $\mathrm{pH} 5.6$, area $($ time $\times \mathrm{pH})$ spent below $\mathrm{pH} 6.0$, and area spent below $\mathrm{pH} 5.6$ for each $24 \mathrm{~h}$ period.

\section{Rumen Fluid Sampling and Analysis}

Rumen fluid samples were collected from all cows at $15 \mathrm{~min}$ before feeding and $6 \mathrm{~h}$ after feeding on Tuesdays and Thursdays of each experimental week. In noncannulated cows, rumen fluid was collected using a Geishauser oral probe and the first $200 \mathrm{~mL}$ of collected fluid was discarded to avoid saliva contamination (Duffield et al., 2004). In ruminally cannulated cows, rumen fluid was sampled from the ventral sac of the rumen. Ruminal contents were strained through 4 layers of cheesecloth and divided into 2 portions. The first portion of samples were transferred into $50-\mathrm{mL}$ sterile tubes and kept on ice until transported to the laboratory for the initial processing before LPS determination as described by Gozho et al. (2005). In brief, rumen fluid samples were centrifuged at 10,000 $\times g$ for $45 \mathrm{~min}$. The supernatant was aspirated gently to prevent its mixing with the pellet and passed through a disposable $0.22-\mu \mathrm{m}$ LPS-free filter (Millex, Millipore Corporation, Bedford, MA). The filtrate was collected in a sterile, depyrogenated glass tube (previ- 
Table 1. Ingredients, nutrient composition, and forage to concentrate ratio (F:C) of TMR in a 6-wk period during which dietary alfalfa hay was gradually replaced with alfalfa pellets to induce low $\mathrm{pH}$

\begin{tabular}{|c|c|c|c|c|c|c|}
\hline \multirow[b]{2}{*}{ Item } & \multicolumn{6}{|c|}{ Week } \\
\hline & 1 & 2 & 3 & 4 & 5 & 6 \\
\hline \multicolumn{7}{|l|}{ Ingredient, \% of DM } \\
\hline Energy supplement $^{1}$ & 39 & 39 & 39 & 39 & 39 & 39 \\
\hline Protein supplement ${ }^{2}$ & 4.5 & 4.5 & 4.5 & 4.5 & 4.5 & 4.5 \\
\hline Roasted soybeans & 6.5 & 6.5 & 6.5 & 6.5 & 6.5 & 6.5 \\
\hline Alfalfa hay & 50 & 42 & 34.0 & 26 & 18 & 10 \\
\hline Alfalfa pellets & 0.0 & 8 & 16 & 24 & 32 & 40 \\
\hline $\mathrm{F}: \mathrm{C}$ & $50: 50$ & $50: 50$ & $50: 50$ & $50: 50$ & $50: 50$ & $50: 50$ \\
\hline \multicolumn{7}{|l|}{ Nutrient composition } \\
\hline DM, \% & 74.5 & 74.4 & 74.3 & 74.3 & 77.4 & 73.3 \\
\hline $\mathrm{CP}, \%$ of $\mathrm{DM}$ & 17.1 & 18.0 & 18.7 & 18.3 & 18.7 & 17.3 \\
\hline $\mathrm{ADF}, \%$ of $\mathrm{DM}$ & 20.6 & 22.8 & 23.6 & 25.1 & 20.6 & 23.0 \\
\hline $\mathrm{NDF}, \%$ of $\mathrm{DM}$ & 36.3 & 35.2 & 34.0 & 35.2 & 36.9 & 35.4 \\
\hline $\mathrm{NFC}^{3}, \%$ of $\mathrm{DM}$ & 33.5 & 34.4 & 33.8 & 33.4 & 33.5 & 34.4 \\
\hline Starch, \% of DM & 21.8 & 22.4 & 22.0 & 21.7 & 21.8 & 22.4 \\
\hline Crude fat, $\%$ of DM & 5.66 & 5.78 & 6.11 & 5.68 & 6.41 & 5.62 \\
\hline Ash, \% of DM & 7.4 & 6.6 & 7.4 & 7.4 & 7.0 & 7.1 \\
\hline $\mathrm{Ca}, \%$ of DM & 0.76 & 0.87 & 0.98 & 1.03 & 1.05 & 1.07 \\
\hline $\mathrm{P}, \%$ of $\mathrm{DM}$ & 0.51 & 0.52 & 0.54 & 0.51 & 0.49 & 0.46 \\
\hline $\mathrm{K}, \%$ of $\mathrm{DM}$ & 1.37 & 1.43 & 1.50 & 1.42 & 1.43 & 1.44 \\
\hline $\mathrm{Mg}, \%$ of $\mathrm{DM}$ & 0.26 & 0.27 & 0.29 & 0.30 & 0.30 & 0.29 \\
\hline $\mathrm{Na}, \%$ of $\mathrm{DM}$ & 0.22 & 0.23 & 0.23 & 0.26 & 0.25 & 0.23 \\
\hline Predicted $\mathrm{NE}_{\mathrm{L}},{ }^{4} \mathrm{Mcal} / \mathrm{kg}$ of DM & 1.63 & 1.63 & 1.64 & 1.64 & 1.65 & 1.65 \\
\hline
\end{tabular}

${ }^{1}$ Energy supplement contained $54.0 \%$ rolled barley, $15.7 \%$ wheat shorts, $7.7 \%$ canola meal, $6.0 \%$ ground wheat, $4.1 \%$ corn gluten meal, $4.0 \%$ vegetable oil, $2.0 \%$ dried corn distillers grain, $1.9 \%$ soybean meal, $1.48 \%$ calcium carbonate, $0.80 \%$ Dynamate (Mosaic Company, Plymouth, MN), 0.68\% dicalcium phosphate, 0.64\% salt, $0.42 \%$ cane molasses, $0.20 \%$ luprosil salt (calcium propionate), $0.13 \%$ pellet binder, $0.09 \%$ oat hulls, $0.05 \%$ vitamin $\mathrm{ADE}$ premix (vitamin A, 16,800 IU/kg; vitamin D, 2,215 IU/kg; vitamin E, $75 \mathrm{IU} / \mathrm{kg}$, DM basis), $0.05 \%$ trace mineral mix, $0.02 \%$ Se.

${ }^{2}$ Protein supplement contained: $42.0 \%$ dried distillers grain, $7.0 \%$ fish meal, $22.5 \%$ canola meal, $20.0 \%$ soybean meal, $3.2 \%$ beet molasses, $0.3 \%$ niacin, and $5.0 \%$ sodium bicarbonate.

${ }^{3}$ Nonfiber carbohydrates $=100-(\mathrm{NDF} \%+\mathrm{CP} \%+$ Crude fat $\%+$ Ash $\%)$.

${ }^{4} \mathrm{NE}_{\mathrm{L}}$ values are predicted using CNCPS (Cornell Net Carbohydrate and Protein System) software version 5.0.4, Cornell University, Ithaca, NY.

ously heated at $180^{\circ} \mathrm{C}$ for $4 \mathrm{~h}$ ) and heated at $100^{\circ} \mathrm{C}$ for $30 \mathrm{~min}$. Samples were cooled at room temperature $\left(19^{\circ} \mathrm{C}\right)$ for $10 \mathrm{~min}$ and stored at $-20^{\circ} \mathrm{C}$ for subsequent LPS measurement. The second portion of each rumen fluid sample was immediately centrifuged at $1,900 \times$ $g$ for $15 \mathrm{~min}$ and supernatant stored at $-20^{\circ} \mathrm{C}$ until analyzed for osmolality, VFA, and ammonia. Concentrations of VFA (acetate, propionate, butyrate, valerate, isobutyrate, and isovalerate) were determined by gas chromatography as described by Bhandari et al. (2007). Ammonia nitrogen concentration of rumen fluid samples was determined using a colorimetric technique as described by Bhandari et al. (2007). Osmolality of rumen fluid samples was determined by freezing point depression using an automatic osmometer (Advanced single sample micro-osmometer Model 3300, Advanced Instruments Inc., Norwood, MA).

Free rumen LPS content was determined by a chromogenic Limulus amebocyte lysate (LAL) end-point assay (QCL-1000, Lonza Group Ltd., Basel, Switzerland). Pretreated rumen samples were diluted until their LPS concentrations were in the range of 0.1 to 1 endotoxin unit $(\mathbf{E U}) / \mathrm{mL}$ relative to the reference endotoxin (Escherichia coli O111:B4), and assayed as described by Gozho et al. (2005).

\section{Blood Sampling and Analysis}

Blood samples were collected by tail venipuncture from each cow at $15 \mathrm{~min}$ before feeding and $6 \mathrm{~h}$ after feeding on Tuesdays and Thursdays of each experimental week. Samples were collected in blank and heparinized 10-mL evacuated tubes (Fisher Scientific, Fairlawn, NJ) for serum and plasma collection, respectively. The serum evacuated tubes were allowed to clot at room temperature $\left(19^{\circ} \mathrm{C}\right)$ for $45 \mathrm{~min}$, and then centrifuged at $1,900 \times g$ for $15 \mathrm{~min}$. Subsequently, serum was aspirated and stored at $-20^{\circ} \mathrm{C}$ until it was used for haptoglobin $(\mathbf{H p})$ analysis. Plasma was harvested by centrifuging heparinized evacuated tubes at 1,900 $\times g$ for $15 \mathrm{~min}$. A portion of plasma was transferred to pyrogen-free glass tubes and stored at $-20^{\circ} \mathrm{C}$ for LPS analysis. The rest 
Table 2. Nutrient composition of TMR ingredients

\begin{tabular}{|c|c|c|c|c|c|}
\hline \multirow[b]{2}{*}{ Item } & \multicolumn{5}{|c|}{ TMR ingredient } \\
\hline & $\begin{array}{c}\text { Energy } \\
\text { supplement }\end{array}$ & $\begin{array}{c}\text { Protein } \\
\text { supplement }\end{array}$ & Soybeans & Alfalfa hay & Alfalfa pellet \\
\hline DM, $\%$ & 90.4 & 91.7 & 95.7 & 89.5 & 94.1 \\
\hline $\mathrm{CP}, \%$ of $\mathrm{DM}$ & 17.2 & 28.9 & 26.7 & 11.2 & 15.3 \\
\hline $\mathrm{ADF}, \%$ of $\mathrm{DM}$ & 8.6 & 12.7 & 17.2 & 37.8 & 36.2 \\
\hline NDF, $\%$ of DM & 19.4 & 28.9 & 20.5 & 54.7 & 50.0 \\
\hline $\mathrm{NFC}^{1}{ }^{1} \%$ of $\mathrm{DM}$ & 47.5 & 18.6 & 17.1 & 23.0 & 24.9 \\
\hline Starch, \% of DM & 34.2 & 3.9 & 4.7 & 1.2 & 1.3 \\
\hline Crude fat, $\%$ of DM & 7.3 & 7.01 & 18.5 & 1.4 & 1.4 \\
\hline Ash, \% of DM & 2.0 & 14.5 & 4.8 & 7.5 & 7.9 \\
\hline $\mathrm{Ca}, \%$ of $\mathrm{DM}$ & 0.94 & 2.95 & 0.17 & 0.58 & 1.14 \\
\hline $\mathrm{P}, \%$ of DM & 0.71 & 1.07 & 0.65 & 0.23 & 0.20 \\
\hline $\mathrm{K}, \%$ of $\mathrm{DM}$ & 1.00 & 1.18 & 1.61 & 1.78 & 1.70 \\
\hline $\mathrm{Mg}, \%$ of $\mathrm{DM}$ & 0.34 & 0.33 & 0.25 & 0.18 & 0.18 \\
\hline $\mathrm{Na}, \%$ of $\mathrm{DM}$ & 0.33 & 1.57 & 0.01 & 0.03 & 0.03 \\
\hline
\end{tabular}

of plasma was divided into $2 \mathrm{~mL}$ aliquots and stored at $-20^{\circ} \mathrm{C}$ until it was analyzed for serum amyloid A (SAA), LPS binding protein (LBP), glucose, and lactate. Plasma glucose and lactate were analyzed using a blood gas and electrolyte analyzer (Nova Stat Profile M, Nova Biomedical Corp., Waltham, MA) as described by Bhandari et al. (2007).

LPS Analysis in Blood Plasma. The concentration of LPS in plasma was determined by a chromogenic kinetic LAL assay (Kinetic-QCL, Lonza Group Ltd.) with a minimum detection limit of $0.005 \mathrm{EU} /$ $\mathrm{mL}$. Before the LAL assay, samples were pretreated as described by Khafipour et al. (2009). In brief, frozen plasma samples were thawed at $37^{\circ} \mathrm{C}$, vortexed, and $100 \mu \mathrm{L}$ of each sample was diluted at least 10-fold with pyrogen-free water. Diluted samples were incubated at $37^{\circ} \mathrm{C}$ for $30 \mathrm{~min}$, then heated at $75^{\circ} \mathrm{C}$ for $15 \mathrm{~min}$ and cooled down to room temperature $\left(19^{\circ} \mathrm{C}\right)$ for $45 \mathrm{~min}$. Then, a metallo-modified polyanionic dispersant called Pyrosperse (Lonza Group Ltd.) was added to the test samples at a ratio of $1 / 200(\mathrm{vol} / \mathrm{vol}$ ) before LAL testing. The kinetic LAL assay was performed in a 96-well microplate according to manufacturer's instructions. The appearance of a yellow color was monitored over time using an incubating microplate spectrophotometer (Spectra Max 340 PC, Molecular Devices Corporation, Sunnyvale, CA) to determine the reaction time, which is defined as the time required for absorbance to increase 0.2 OD. A $\log / \log$ linear correlation of the mean reaction time of each standard with its corresponding endotoxin concentration was performed to create a standard curve and predict endotoxin concentration of test samples. To verify the lack of product inhibition, samples were spiked with $10 \mu \mathrm{L}$ of $2 \mathrm{EU} / \mathrm{mL}$ standard. A recovery range between 50 to $150 \%$ of the spiked concentration was considered as noninhibitory dilution.
All samples were tested in duplicate and results were accepted when intraassay coefficient of variation was less than $10 \%$. With regard to initial 10-fold dilutions of samples, the minimum detection level of LPS in plasma was $0.05 \mathrm{EU} / \mathrm{mL}$ with this method.

Blood Acute Phase Proteins. Serum concentrations of $\mathrm{Hp}$ and plasma concentrations of SAA were determined using ELISA kits (TP-801, and TP-802, respectively, Tri-Delta Diagnostics Inc., Morris Plains, NJ) as described by Gozho et al. (2005). Plasma concentrations of LBP were measured using a commercially available kit (HK503, HyCult Biotechnology, Uden, the Netherlands). Samples were initially diluted 1:5 for Hp, 1:500 for SAA, and 1:1000 for LBP and assayed according to the manufacturer's instructions. Samples were analyzed in duplicate and absorbance values were read at $630 \mathrm{~nm}$ for $\mathrm{Hp}$ and $450 \mathrm{~nm}$ for SAA and LBP using a microplate spectrophotometer (Spectra Max 340 PC, Molecular Devices Corp., Sunnyvale, CA, and BioRad model 3550, Hercules, CA, respectively). The minimum detection limit of these assays was $50 \mu \mathrm{g} /$ $\mathrm{mL}, 0.3 \mu \mathrm{g} / \mathrm{mL}$, and $1.6 \mathrm{ng} / \mathrm{mL}$ for $\mathrm{Hp}$, SAA, and LBP, respectively.

\section{Milk Sampling and Analysis}

Cows were milked twice daily in their stall at approximately $0400 \mathrm{~h}$ and $1600 \mathrm{~h}$. Milk yield was recorded using TruTest regulation meters (Westfalia Surge, Mississauga, Ontario, Canada) with the accuracy of $5 \%$ or $0.3 \mathrm{~L}$. Milk samples $(50 \mathrm{~mL})$ from 4 consecutive milkings during each sampling week were collected, preserved with 2-bromo-2-nitropropane-1,3 diol, and stored at $4^{\circ} \mathrm{C}$ until analyzed for fat and protein at the laboratory of the Dairy Farmers of Manitoba (Winnipeg, Manitoba, Canada) by near-infrared analysis using the MilkoScan 
Table 3. Intake, milk yield, and milk components production of dairy cows in a 6-wk period during which dietary alfalfa hay was gradually replaced with alfalfa pellets to induce low $\mathrm{pH}$

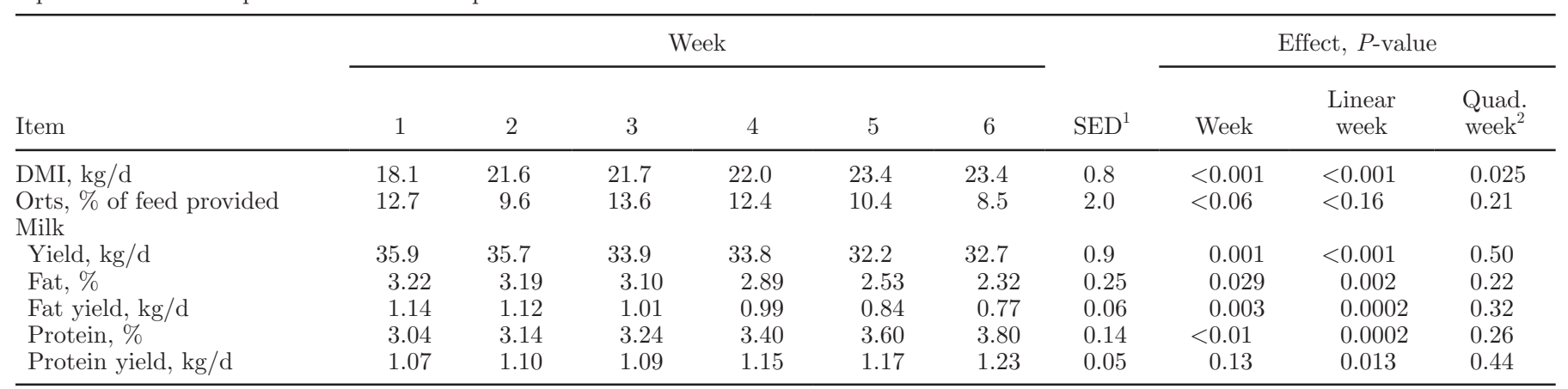

${ }^{1} \mathrm{SED}=$ standard error of difference between treatments.

${ }^{2}$ Quad. = quadratic.

303AB (Foss Electric, Hillerød, Denmark). The infrared analysis was calibrated by the Babcock method for milk fat analysis (AOAC, 1990; method 989.04) and the Kjeldahl method for nitrogen/protein nitrogen analysis in milk (AOAC, 1990; method 991.22).

\section{Statistical Analysis}

Data from 6 wk were analyzed as repeated measures using the MIXED procedure of SAS (2004). For intake, milk production, and rumen $\mathrm{pH}$ parameters, the effect of week - which corresponded with the inclusion rate of alfalfa pellets - was considered fixed. The effects of cow and interaction between cow and week were considered random. The effect of day within week was considered random and analyzed as a repeated measure. For rumen VFA and ammonia, the additional effect of postfeeding hours and their interactions with week were considered fixed. Interactions of hour and cow and of hour and day within week were considered random. Because free rumen LPS was only determined during one day of each week, day was not included in the statistical model. To obtain a normal distribution and homogeneous residual error, ruminal LPS data were log-transformed. Tukey's multiple range tests were used to compare the differences among treatment means. Effects were considered significant at $P<0.05$. Trends were discussed at $P<$ 0.10 .

\section{RESULTS}

\section{Diets, Feed Intake, Milk Yield, and Milk Composition}

Replacing alfalfa hay with alfalfa pellets resulted in average daily consumption of $1.7,3.5,5.3,7.5$, and $9.5 \mathrm{~kg}$ (DM basis) of alfalfa pellets during wk 2 to 6 . Although alfalfa pellets contained more DM (94.1 vs. $89.5 \%$ ), CP (15.3 vs. $11.2 \%$ of DM), and Ca (1.14 vs.
$0.58 \%$ of DM), and less NDF (50 vs. $54.7 \%$ of DM) than alfalfa hay, the replacement of alfalfa hay with alfalfa pellets did not change the chemical composition of TMR during the $6 \mathrm{wk}$ of the experiment (Table 1 ). The mean and the standard deviation of physical parameters of alfalfa pellets including length, diameter, bulk density, and water-holding capacity were $8.63 \pm$ $2.91 \mathrm{~mm}, 6.56 \pm 0.13 \mathrm{~mm}, 1.14 \mathrm{~g} / \mathrm{mL}$, and $6.55 \mathrm{~g} / \mathrm{g}$, respectively.

Replacing $40 \%$ of alfalfa hay with alfalfa pellets during the 6-wk period quadratically increased the DMI from $18.1 \mathrm{~kg} / \mathrm{d}$ in wk 1 to $23.4 \mathrm{~kg} / \mathrm{d}$ in wk $6(P=0.025$; Table 3 ). This replacement linearly decreased milk yield (from 35.9 to $32.7 \mathrm{~kg} / \mathrm{d} ; P<0.001$ ), milk fat (from 3.22 to $2.32 \% ; P=0.002$ ), and fat yield (from 1.14 to 0.77 $\mathrm{kg} / \mathrm{d} ; P=0.0002)$, but linearly increased milk protein percentage (from 3.04 to $3.80 \% ; P=0.0002$ ) and yield (from 1.07 to $1.23 \mathrm{~kg} / \mathrm{d} ; P=0.013$; Table 3 ).

\section{Ruminal Parameters}

Gradual replacement of alfalfa hay with alfalfa pellet linearly decreased the average daily $\mathrm{pH}$ from 6.35 in wk 1 to 5.78 in wk $6(P<0.001$; Table 4$)$. From wk 3 onwards, rumen $\mathrm{pH}$ was $<5.6$ for more than $180 \mathrm{~min} / \mathrm{d}$ indicating that SARA was successfully induced during these weeks (Figure 1). This duration increased to the maximum of $558 \mathrm{~min} / \mathrm{d}$ in wk 4 and then declined $(P$ $=0.04)$ to 510 and $447 \mathrm{~min} / \mathrm{d}$ during wk 5 and wk 6 , respectively (Figure 1). Based on the duration and area under $\mathrm{pH} 5.6$, the most severe rumen $\mathrm{pH}$ depression was obtained in wk 4 and 5 (Table 4). During the 6 wk of the experiment, duration and area under $\mathrm{pH} 6$ also linearly increased from 312 to $975 \mathrm{~min} / \mathrm{d}(P<$ $0.001)$, and from 102 to $340 \mathrm{~min} \times \mathrm{pH} / \mathrm{d}(P=0.001)$, respectively.

Across sampling times, replacing alfalfa hay with alfalfa pellets linearly increased total VFA (121.9 vs. 


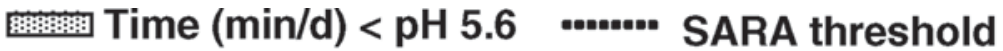 \\ Average daily $\mathrm{pH}$ \\ (at least $180 \mathrm{~min} / \mathrm{d}<\mathrm{pH} \mathrm{5.6)}$}

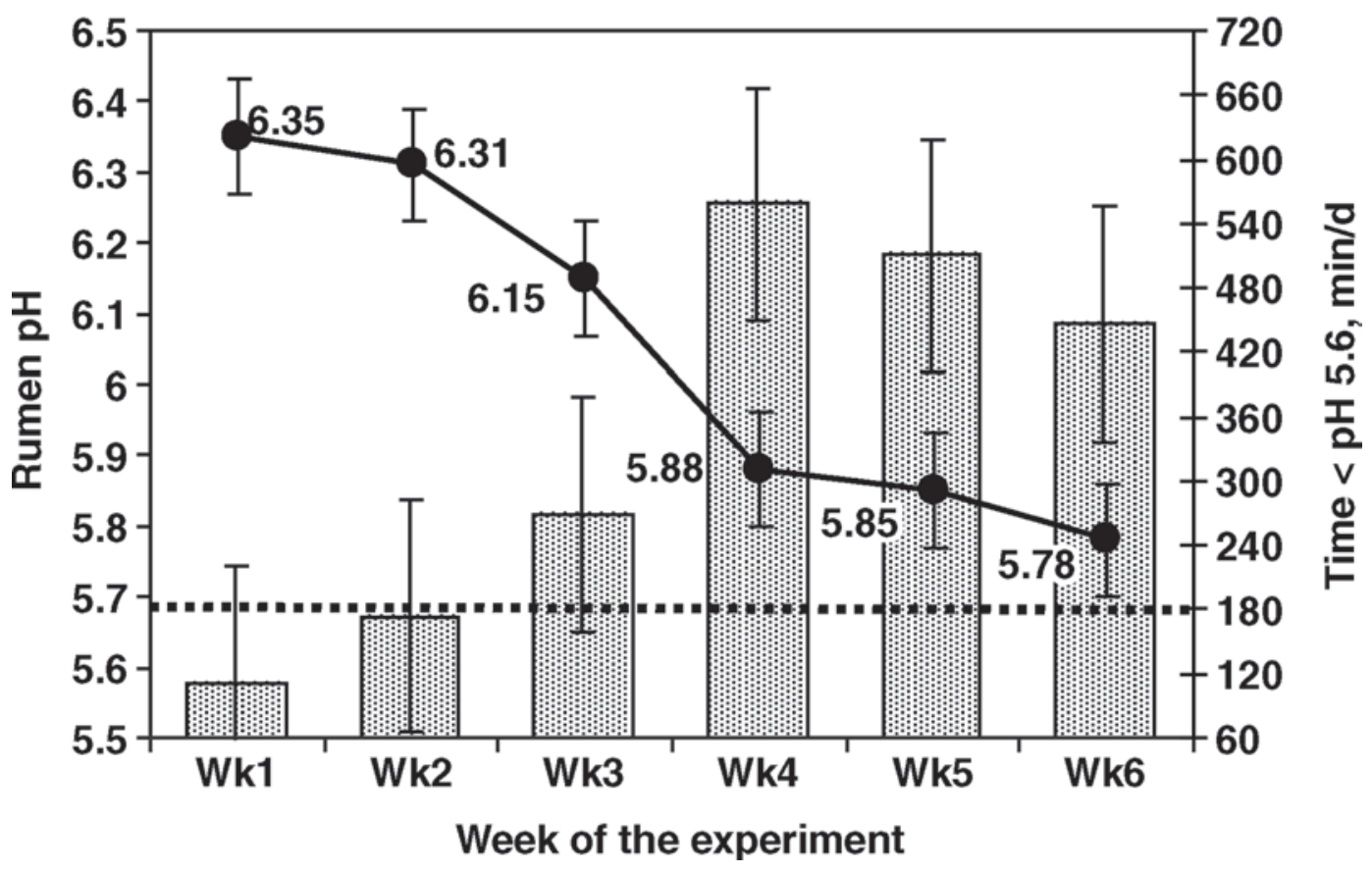

Figure 1. Weekly averages of rumen $\mathrm{pH}$ and time spent below $\mathrm{pH} 5.6$ of dairy cows in a 6 -wk period during which dietary alfalfa hay was gradually replaced with alfalfa pellets to induce low pH. Error bars indicate standard error of difference between treatments (SED).

$90.0 \mathrm{~m} M ; P<0.001)$, acetate $(66.8$ vs. $53.9 \mathrm{~m} M ; P=$ $0.003)$, propionate $(39.6$ vs. $21.5 \mathrm{mM} ; P<0.001)$, and valerate (2.0 vs. $1.1 \mathrm{~m} M ; P<0.001)$ in the rumen from wk 1 to 6 (Table 5). This replacement quadratically increased butyrate concentration from $10.8 \mathrm{~m} M$ in wk 1 to $12.3 \mathrm{~m} M$ in wk $6(P=0.009)$, but did not affect total branched-chain VFA (isobutyrate + isovalerate), which averaged $2.2 \mathrm{mM}$ across all weeks. Feeding alfalfa pellets decreased the acetate to propionate ratio $(\mathbf{A c}: \mathbf{P r})$ in the rumen from 2.62 to 1.73 , and tended to reduce the daily average of rumen ammonia from 7.0 to $5.5 \mathrm{mg} / \mathrm{dL}(P=0.06$; Table 5$)$. Concentrations of VFA were significantly increased by hours postfeeding (Table 5, Figure 2). The interaction of week-which corresponded with the inclusion rate of alfalfa pelletswith hours postfeeding on total VFA in rumen is shown in Figure 2.

Across sampling times, gradual replacement of alfalfa hay with alfalfa pellets linearly increased rumen osmolality $(293.8$ in wk 6 vs. $277.7 \mathrm{mmol} / \mathrm{kg}$ in wk $1 ; P=$ $0.002)$ and free LPS concentration $(145,593$ in wk 6 vs. $42,122 \mathrm{EU} / \mathrm{mL}$ in wk $1 ; P<0.001$; Table 6$)$. Rumen

Table 4. Rumen $\mathrm{pH}$ of dairy cows based on continuous monitoring using indwelling probes during a 6 -wk period where dietary alfalfa hay was gradually replaced with alfalfa pellets to induce low $\mathrm{pH}$

\begin{tabular}{|c|c|c|c|c|c|c|c|c|c|c|}
\hline \multirow[b]{2}{*}{ Item } & \multicolumn{6}{|c|}{ Week } & \multirow[b]{2}{*}{$\mathrm{SED}^{1}$} & \multicolumn{3}{|c|}{ Effect, $P$-value } \\
\hline & 1 & 2 & 3 & 4 & 5 & 6 & & Week & $\begin{array}{c}\text { Linear } \\
\text { week }\end{array}$ & $\begin{array}{l}\text { Quad. } \\
\text { week }^{2}\end{array}$ \\
\hline Time $<\mathrm{pH} 5.6, \mathrm{~min} / \mathrm{d}$ & 112 & 174 & 268 & 558 & 510 & 447 & 109.5 & 0.04 & 0.004 & 0.24 \\
\hline Time $<\mathrm{pH} 6, \mathrm{~min} / \mathrm{d}$ & 312 & 437 & 517 & 1,002 & 940 & 975 & 108 & $<0.001$ & $<0.001$ & 0.28 \\
\hline Area $<\mathrm{pH} 5.6, \min \times \mathrm{pH} / \mathrm{d}$ & 24 & 41 & 93 & 107 & 110 & 69 & 41 & 0.25 & 0.09 & 0.09 \\
\hline
\end{tabular}

${ }^{1} \mathrm{SED}=$ standard error of difference between treatments.

${ }^{2}$ Quad. = quadratic. 
Table 5. Rumen fluid composition and blood metabolites of dairy cows in a 6-wk period during which dietary alfalfa hay was gradually replaced with alfalfa pellets to induce low $\mathrm{pH}$

\begin{tabular}{|c|c|c|c|c|c|c|c|c|c|c|c|c|}
\hline Item $^{1}$ & \multicolumn{6}{|c|}{ Week } & $\mathrm{SED}^{2}$ & \multicolumn{5}{|c|}{ Effects, $P$-value } \\
\hline \multicolumn{13}{|l|}{ Ruminal parameters } \\
\hline \multicolumn{13}{|l|}{ VFA, $\mathrm{m} M$} \\
\hline Total & 90.0 & 90.5 & 99.2 & 120.4 & 130.5 & 121.9 & 6.3 & 0.008 & $<0.001$ & 0.47 & $<0.001$ & 0.001 \\
\hline Acetate & 53.9 & 52.7 & 55.0 & 67.4 & 74.5 & 66.8 & 3.7 & 0.02 & 0.003 & 0.69 & $<0.001$ & $<0.001$ \\
\hline Valerate & 1.1 & 1.3 & 1.6 & 1.9 & 2.1 & 2.0 & 0.2 & 0.009 & $<0.001$ & 0.18 & $<0.001$ & 0.42 \\
\hline Total branched chain ${ }^{5}$ & 2.8 & 2.4 & 3.6 & 1.9 & 1.2 & 1.2 & 0.6 & 0.17 & 0.51 & 0.30 & 0.02 & 0.23 \\
\hline Acetate: Propionate & 2.62 & 2.55 & 2.22 & 2.21 & 2.00 & 1.73 & 0.18 & 0.02 & $<0.001$ & 0.68 & $<0.001$ & $<0.001$ \\
\hline Ammonia, mg/dL & 7.0 & 8.1 & 7.4 & 6.4 & 5.7 & 5.5 & 0.9 & 0.16 & 0.06 & 0.43 & $<0.04$ & $<0.01$ \\
\hline \multicolumn{13}{|l|}{ Blood parameters } \\
\hline Glucose, mg/dL & 67.4 & 64.7 & 66.5 & 68.3 & 70.4 & 67.9 & 1.95 & 0.12 & 0.078 & 0.85 & 0.01 & 0.83 \\
\hline Lactate, $\mathrm{m} M$ & 1.00 & 0.98 & 1.14 & 2.25 & 3.46 & 1.86 & 0.64 & 0.004 & 0.002 & 0.37 & 0.21 & 0.63 \\
\hline
\end{tabular}

${ }^{1}$ Average concentration per day across sampling times.

${ }^{2} \mathrm{SED}=$ standard error of difference between treatments.

${ }^{3}$ Quad. = quadratic.

${ }^{4}$ Time of sampling 15 min before and at $6 \mathrm{~h}$ after feeding in 2 nonconsecutive days during each week. The first day of sampling was $2 \mathrm{~d}$ after diet change.

${ }^{5}$ Isobutyrate + isovalerate.

LPS concentration did not vary following feeding during wk 1 and 2 , but declined by $6 \mathrm{~h}$ postfeeding from wk 3 onward $(P=0.039)$ when SARA was induced (Table $6)$. Averaged across wk 3 to wk 6, free rumen LPS concentration decreased from 153,208 EU/mL before feeding to $96,961 \mathrm{EU} / \mathrm{mL}$ at $6 \mathrm{~h}$ after feeding.

\section{Blood Parameters}

Regardless of the week of experiment and sampling time, peripheral LPS concentration remained below the minimum detection level of $0.05 \mathrm{EU} / \mathrm{mL}$ (Table 6). Blood concentrations of the acute phase proteins Hp, SAA, and LBP linearly decreased during the 6 wk of

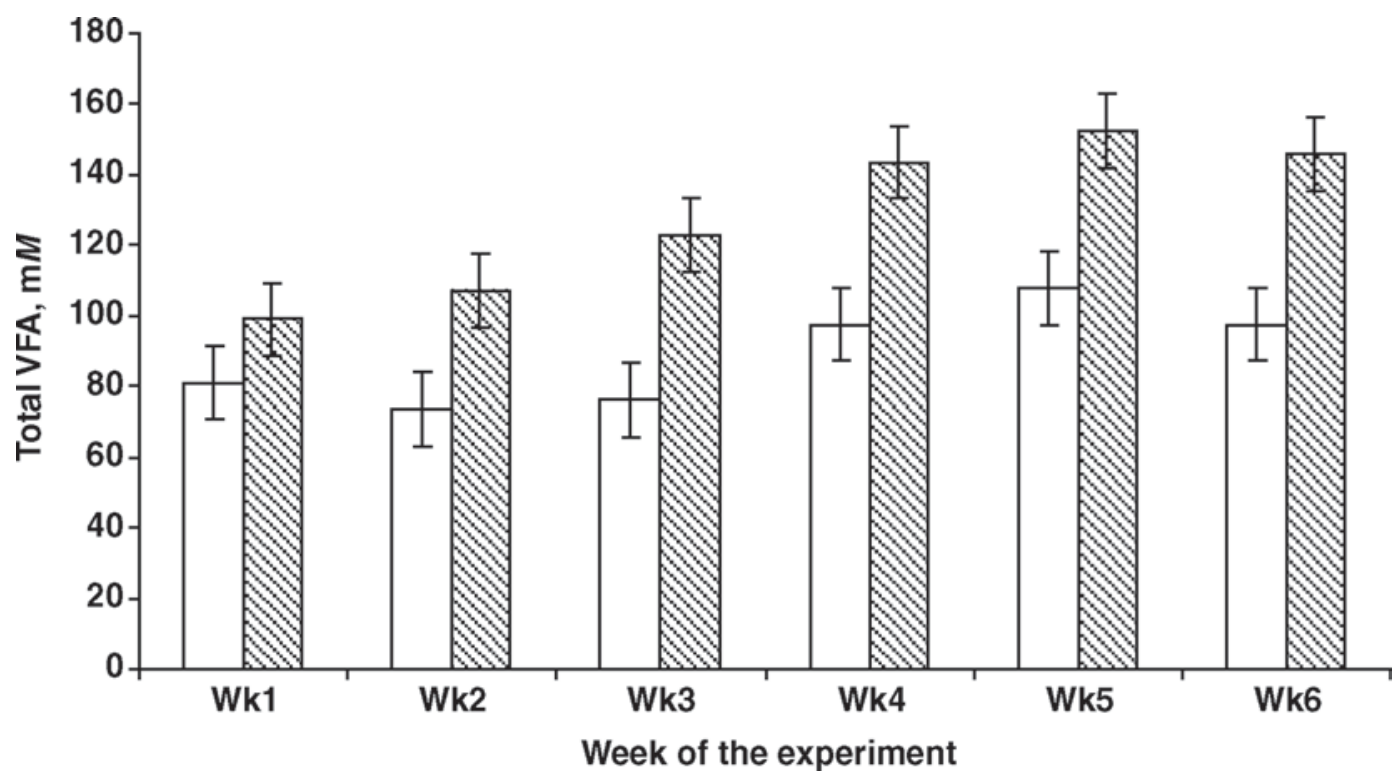

Figure 2. Rumen total VFA ( $\mathrm{m} M / \mathrm{d}$ ) before (unshaded bars) and at $6 \mathrm{~h}$ (shaded bars) after feeding in dairy cows in a 6 -wk period during which dietary alfalfa hay was gradually replaced with alfalfa pellets to induce low pH. Error bars indicate standard error of difference between treatments (SED). 
Table 6. Rumen and plasma LPS and rumen osmolality of dairy cows in a 6-wk period during which dietary alfalfa hay was gradually replaced with alfalfa pellets to induce low $\mathrm{pH}$

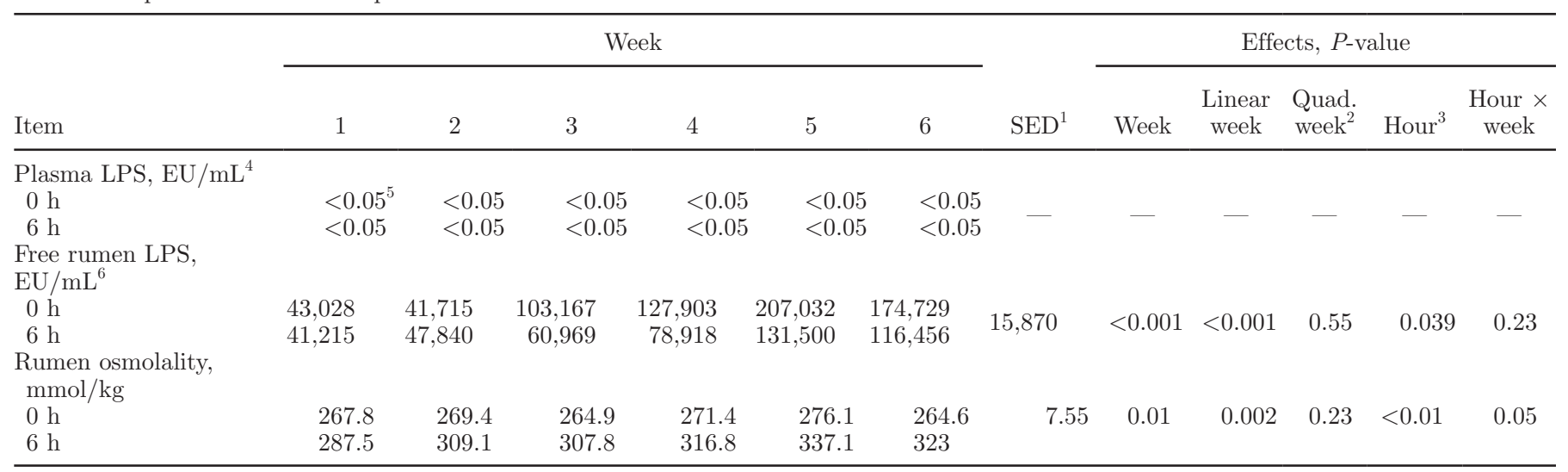

${ }^{1} \mathrm{SED}=$ standard error of difference between treatments.

${ }^{2}$ Quad. = quadratic.

${ }^{3}$ Time of rumen fluid sampling 15 min before and at $6 \mathrm{~h}$ after feeding in 2 nonconsecutive days during each week. The first day of sampling was $2 \mathrm{~d}$ after diet change.

${ }^{4} \mathrm{EU}=$ endotoxin unit.

${ }^{5}$ The minimum detection level of plasma LPS with this method was $0.05 \mathrm{EU} / \mathrm{mL}$.

${ }^{6}$ Statistical analyses were conducted on $\log _{10}$-transformed data.

the experiment from 56 to $12 \mu \mathrm{g} / \mathrm{mL}(P<0.0001), 23.1$ to $6.9 \mu \mathrm{g} / \mathrm{mL}(P=0.003)$, and 7.2 to $2.6 \mu \mathrm{g} / \mathrm{mL}(P=$ 0.038 ), respectively (Table 7 ).

Across sampling times, replacement of alfalfa hay with alfalfa pellets did not affect blood glucose concentration, but linearly increased $(P=0.002)$ blood lactate (Table 5$)$. The peak of lactate $(3.46 \mathrm{mM})$ in blood was observed during wk 5 .

\section{DISCUSSION}

The current definitions of subacute ruminal acidosis are based on rumen $\mathrm{pH}$ (Plaizier et al., 2008). There is no general agreement on the $\mathrm{pH}$ threshold that is definitive of SARA, as rumen pH of 5.5 (Garrett et al., 1999), between 5.2 and 5.6 (Cooper and Klopfenstein, 1996), 5.8 (Beauchemin et al., 2003), and 6 (Plaizier, 2004) have all been suggested as thresholds for SARA. These thresholds have been suggested based on criteria such as microbial activity in the rumen, health and function of rumen epithelium, and the method of $\mathrm{pH}$ measurement. We defined SARA as daily episodes of low rumen $\mathrm{pH}$ between 5.2 and 5.6 for at least $180 \mathrm{~min} / \mathrm{d}$ (Gozho et al., 2005). The duration of time below $\mathrm{pH} 5.6$ was particularly included in our definition because rumen $\mathrm{pH}$ fluctuates throughout the day and we have observed that at least $3 \mathrm{~h} / \mathrm{d}$ of $\mathrm{pH}<5.6$ is required to activate an inflammatory response during SARA (Gozho et al., $2005 ; 2006)$. Based on this definition, the replacement of $16 \%$ of the DM of alfalfa hay with alfalfa pellets induced SARA in this study $(268 \mathrm{~min} / \mathrm{d}$ of $\mathrm{pH}<5.6)$. The replacement of 24 and $32 \%$ of the DM of alfalfa hay with alfalfa pellets further decreased rumen $\mathrm{pH}$ and resulted in average duration of rumen $\mathrm{pH}$ below 5.6 for

Table 7. Blood ${ }^{1}$ concentration of serum amyloid-A (SAA), haptoglobin (Hp), and LPS binding protein (LBP) of dairy cows in a 6 -wk period during which dietary alfalfa hay was gradually replaced with alfalfa pellets to induce low $\mathrm{pH}$

\begin{tabular}{|c|c|c|c|c|c|c|c|c|c|c|}
\hline \multirow[b]{2}{*}{ Item } & \multicolumn{6}{|c|}{ Week } & \multicolumn{4}{|c|}{ Effect, $P$-value } \\
\hline & 1 & 2 & 3 & 4 & 5 & 6 & $\mathrm{SED}^{2}$ & Week & $\begin{array}{c}\text { Linear } \\
\text { week }\end{array}$ & $\begin{array}{l}\text { Quad. } \\
\text { week }^{3}\end{array}$ \\
\hline Plasma SAA, $\mu \mathrm{g} / \mathrm{mL}$ & 23.1 & 12.3 & 7.8 & 12.3 & 9.6 & 6.9 & 3.9 & 0.013 & 0.003 & 0.11 \\
\hline Serum $\mathrm{Hp}, \mu \mathrm{g} / \mathrm{mL}$ & 56 & 34 & 27 & 28 & 21 & 12 & 6.0 & $<0.0001$ & $<0.0001$ & 0.15 \\
\hline Plasma LBP, $\mu \mathrm{g} / \mathrm{mL}$ & 7.2 & 4.2 & 3.4 & 3.9 & 5.1 & 2.6 & 2.4 & 0.09 & 0.038 & 0.29 \\
\hline
\end{tabular}


558 and $510 \mathrm{~min} / \mathrm{d}$, respectively. These durations were greater than $506,412,328,309$, and $279 \mathrm{~min} / \mathrm{d}$ of rumen $\mathrm{pH}$ below 5.6 reported by Krause and Oetzel (2005), AlZahal et al. (2008), Bevans et al. (2005), Gozho et al. (2007), and Khafipour et al. (2009), respectively, who induced SARA by feeding high-grain diets.

The greater rumen $\mathrm{pH}$ depression during alfalfa pellet-induced SARA compared with the grain-induced SARA in earlier studies and the differences in the rumen $\mathrm{pH}$ depression among these earlier studies were caused by the dietary differences between the models of SARA induction. Krause and Oetzel (2005), Gozho et al. (2007), and Khafipour et al. (2009) induced SARA by replacing 20,25 , and 21 of the DM of the TMR with wheat-barley pellets, respectively. AlZahal et al. (2008) induced SARA by replacing 18.9 and $9.5 \%$ of the DM of the TMR with ground wheat and ground barley, and Bevans et al. (2005) induced SARA by replacing $25 \%$ of the DM of the TMR with dry-rolled barley. Induction of SARA by increasing the content of starch and reducing the $\mathrm{F}: \mathrm{C}$ ratio of the diet results in accumulation of organic acids in the rumen and reduction of chewing and rumination activity, leading to decreased rumen buffering and increased rumen acidity (Plaizier et al., 2008).

In contrast, the current study induced SARA by replacing alfalfa hay with alfalfa pellets without changing the $\mathrm{F}: \mathrm{C}$ ratio and the dietary content of starch. As a result, the diets fed in wk 4 and 5 of our study, which induced the lowest rumen $\mathrm{pH}$, contained 74 and $82 \%$ of concentrate and pelleted ground forages, and 26 and $18 \%$ of alfalfa hay, respectively. The size of alfalfa pellets was above the recommendations for a particle length that could stimulate chewing and rumination (8.63 vs. $1.18 \mathrm{~mm}$, respectively; Poppi et al., 1980). However, pellets consisted of ground forages, which would have rapidly disintegrated in the rumen. Although we did not measure the fermentability of alfalfa pellets, the increase in rumen VFA to levels similar to grain-induced SARA (Bevans et al., 2005; Gozho et al., 2007) suggests that the alfalfa pellets were highly fermentable. Uden (1988) showed that cows consuming only ground pelleted hay did not ruminate. We assume that alfalfa pellets might not stimulate chewing, saliva production, and rumen buffering. In addition, the forage fraction of the diet in this study contained only alfalfa hay and pellets, whereas the TMR fed during grain-induced SARA in the aforementioned earlier studies consisted of between 30 and $40 \%$ silages. The high DM content of hay and forage pellets compared with silages would have increased sorting against coarse particles (Leonardi et al., 2005) and resulted in less rumen buffering and more $\mathrm{pH}$ depression in alfalfa pellet-induced SARA compared with grain-induced SARA.
Decreased or erratic feed intake have been suggested as indicators of SARA (Kleen et al., 2003) and have been observed when SARA was experimentally induced by feeding a high-grain diet (Bevans et al., 2005; Gozho et al., 2005; Khafipour et al., 2009). Reasons for this reduction can include decreased $\mathrm{pH}$ and contractions in the rumen, increased rumen osmolality, and VFA, especially propionate (Kleen et al., 2003). However, in our study, a similar decline in rumen $\mathrm{pH}$ and similar increases in total VFA and osmolality compared with grain-induced SARA (Bevans et al., 2005; Khafipour et al., 2009) did not reduce feed intake. Moreover, induction of SARA by replacing alfalfa hay with alfalfa pellets progressively increased the DMI during the 6-wk period. This increase could have been due to the change in the physical composition of the diet, which could affect the physical regulation of feed intake. Increasing the dietary content of forage pellets might have decreased the filling effect of the diet in the reticulorumen and increased solid passage rate (Uden, 1988; Allen, 2000). These could result in increased DMI as the density of ingested particles and time for eating and ruminating was increased (Allen, 2000).

Despite a significant increase in DMI, milk yield declined and animals did not gain weight in this study. Uden (1988) noted that feeding ground and pelleted hay reduces solid retention time in the rumen. As a result, the passage rate of small particles from the rumen increases irrespective of their age, which therefore reduces fiber digestibility. On the other and, rumen $\mathrm{pH}$ below 5.8 could inhibit rumen cellulolytic activity and reduce fiber digestibility and feed efficiency. The 3.2 $\mathrm{kg} / \mathrm{d}$ reduction in milk yield that we observed in the current study was close to the 3.3 (Khafipour et al., 2009 ) and $3.5 \mathrm{~kg} / \mathrm{d}$ (Krause and Oetzel, 2005) reductions that were observed during experimentally graininduced SARA and the $2.7 \mathrm{~kg} / \mathrm{d}$ reported in dairy herds experiencing SARA (Stone, 1999). However, the decline in milk fat was greater in alfalfa pellet-induced SARA than grain-induced SARA in the study of Khafipour et al. (2009) or that of dairy herds with SARA in the study of Stone (1999; 0.9 vs. 0.12 and $0.3 \%$, respectively), whereas Krause and Oetzel (2005) reported a $0.56 \%$ increase in milk fat. The greater decline in milk fat in our study might be caused by greater acidity and duration of time $<\mathrm{pH} 5.6$ than is typically observed in cows experiencing SARA (Krause and Oetzel, 2005; Khafipour et al., 2009). Rumen acidity can trigger different mechanisms, including incomplete biohydrogenation of fatty acids in the rumen, that result in milk fat depression (Plaizier et al., 2008).

Alfalfa pellet-induced SARA increased the concentration of free rumen LPS from 42,122 to $145,593 \mathrm{EU} /$ $\mathrm{mL}$. This increase was greater than the reported ranges 
for grain-induced SARA, which were from 24,547 to $128,820 \mathrm{EU} / \mathrm{mL}$, from 28,184 to $107,150 \mathrm{EU} / \mathrm{mL}$, and from 7,900 to $88,700 \mathrm{EU} / \mathrm{mL}$ reported by Gozho et al. (2007), Khafipour et al. (2009), and Emmanuel et al. (2008), respectively. However, in the alfalfa pelletinduced SARA, the free rumen LPS concentration declined by 6 h postfeeding, whereas it sharply increased during grain-induced SARA (Gozho et al., 2006; Khafipour et al., 2009). The concentration of free LPS increases in the rumen during the early hours postfeeding primarily because of the increase in shedding of LPS from rapidly growing gram-negative bacteria (Wells and Russell, 1996; Andersen, 2000). The concentration of free LPS continues to increase later because of the increase in bacterial lysis caused by the lower $\mathrm{pH}$ in the rumen (Andersen, 2000). Provision of additional starch during grain-induced SARA could have triggered the rapid growth of starch/sugar fermenting gram-negative bacteria, such as Prevotella spp., Ruminobacter amylophilus, Succinimonas amylolytica, and Succinivibrio dextrinosolvens (Nagaraja and Titgemeyer, 2007), and thus, increased the shedding of LPS during the early hours postfeeding. In contrast, our study induced SARA without adding starch, and therefore, without providing additional starch to increase the growth of amylolytic gram-negative bacteria. However, the ground pelleted forage could have triggered the growth of cellulolytic gram-negative bacteria such as Fibrobacter succinogenes because the surface area for the bacterial attachment was increased (McAllister et al., 1994). However, the F. succinogenes population is less than $2 \%$ of the rumen bacteria (Tajima et al., 1999). Hence, its contribution to the free rumen LPS pool is small compared with that of other gram-negative bacteria. As a result, free rumen LPS declined during the early hours postfeeding.

Both alfalfa pellet-induced SARA in the present study and grain-induced SARA in earlier studies increased free rumen LPS (Gozho et al., 2007; Emmanuel et al., 2008; Khafipour et al., 2009). However, when plasma LPS was monitored with a similarly sensitive technique, only grain-induced SARA increased LPS in the peripheral plasma (Khafipour et al., 2009). Despite greater free rumen LPS in alfalfa pellet-induced than grain-induced SARA, absence of LPS in the peripheral circulation suggests that free LPS in the rumen is not the cause of LPS translocation to the blood. This view is supported by the findings of Lassman (1980), who reported that infusion of Cr-labeled LPS into the rumen of steers was not followed by LPS translocation into the lymph or portal circulation. Together, these results may suggest that rumen epithelium has a low permeability to LPS and the rate of LPS translocation through the rumen wall must be below its clearance rate by the liver (Andersen and Jarlov, 1990), so that translocation of small amounts of LPS prevents its accumulation in the peripheral blood. However, this hypothesis is challenged by recent observations showing that administration of $500 \mu \mathrm{g} / \mathrm{mL}$ of LPS to the epithelial side of rumen tissue resulted in translocation of LPS across the rumen wall (Emmanuel et al., 2007). However, the concentration of LPS that was applied to the epithelial side of rumen tissue in the study of Emmanuel et al. (2007) was 50 times greater than free rumen LPS concentration during SARA (Gozho et al., 2007; Emmanuel et al., 2008), and that may have disrupted the barrier function of the rumen to a greater extent than would have occurred physiologically.

Previous studies showed that abnormal increase in luminal LPS disrupts the barrier function of the epithelium and increases gut permeability through production of nitric oxide (Chin et al., 2006). However, differences between the composition and stratification of the epithelium of the rumen and of the small and large intestine could result in differences in the effect of LPS on barrier impairment, and therefore, on the rate of LPS translocation from these parts of the gastrointestinal tract (Graham and Simmons, 2005). If we assume that the rate of LPS translocation through the multilayer epithelium of the rumen is below its clearance rate by the liver, then peripheral LPS during grain-induced SARA must be translocated through the simple epithelium of the small or large intestine (Chin et al., 2006). However, before arriving at these sites, free rumen LPS is detoxified in the duodenum, primarily by bile acids (Bertok, 1998). Hence, accumulation of LPS in the terminal ileum and in the large intestine must be due to shedding of LPS from gram-negative bacterial communities in these components of the intestine. Allen (2000) indicated that up to $44 \%$ of starch intake can be digested postruminally. As a result, greater content of dietary starch during grain-induced SARA could have triggered the shedding of LPS from gram-negative bacteria in the terminal ileum and large intestine. Accumulation of free LPS in this part of the intestine probably resulted in barrier failure, which allowed LPS to translocate into the circulatory system and triggered an inflammatory response. In contrast, alfalfa pelletinduced SARA added no additional starch to the diet to modify the profile of bacterial communities of the intestine. This might explain why we could not find any evidence of LPS in the peripheral circulation. Lending support to this hypothesis, a recent study in our group (Li et al., 2008) found that LPS concentration in feces was $\sim 2.5$ times greater in grain-induced SARA than in alfalfa pellet-induced SARA (82,842 vs. $34,179 \mathrm{EU} / \mathrm{mL}$, respectively).

Additional support for our hypothesis is provided by the absence of increases in the acute phase proteins 
SAA, Hp, and LBP in blood, which are inflammatory markers (Horadagoda et al., 1999). In particular, the lack of an LBP response supports this hypothesis, as it is a specific marker of LPS. The LBP binds to LPS to facilitate its transfer to membrane-associated receptors and enhance the immune response. Also, LBP mediates LPS transfer to lipoproteins resulting in neutralization of LPS (Sriskandan and Altmann, 2008). Previous studies showed that grain-induced SARA was accompanied by LPS translocation into the bloodstream (Khafipour et al., 2009) and increased SAA, Hp, and LBP concentrations in the peripheral blood (Gozho et al., 2006; Emmanuel et al., 2008; Khafipour et al., 2009). Despite the similarity in rumen $\mathrm{pH}$ and free rumen LPS between grain and alfalfa pellet-induced SARA, these observations suggest that increased rumen acidity and free LPS are not the sole cause of the inflammatory response seen during grain-induced SARA.

We believe that the level of free LPS in the gut lumen that is required to impair the epithelial barrier function determines the site and rate of LPS translocation. Because rumen epithelium has a multilayered structure and is more complex than the monolayer epithelium of the small and large intestine (Graham and Simmons, 2005), a greater level of LPS would be required to disrupt the barrier function and result in LPS translocation. The minimum level of LPS required to impair the barrier function of rumen or intestinal epithelium remains unknown. Chin et al. (2006) reported that a cytotoxic effect of LPS on enterocyte apoptosis occurred at a luminal concentration of $40 \mu \mathrm{g} / \mathrm{mL}(400,000 \mathrm{EU} / \mathrm{mL})$ after $30 \mathrm{~min}$ of administration of LPS and that these effects increased over time. However, these authors did not monitor the effect of lower concentrations of LPS over a longer time period. Vreugdenhil et al. (1999) found that luminal LPS concentration up to $10 \mu \mathrm{g} /$ $\mathrm{mL}(100,000 \mathrm{EU} / \mathrm{mL})$ did not increase the release of LBP and SAA by colonic adenocarcinoma Caco- 2 cell lines that express structural and functional properties of small intestine enterocytes. This characteristic protects the host from a continuous inflammatory response to the high level of LPS that is present in the lumen. The reported concentration of free rumen LPS is in the range of 88,000 to $170,000 \mathrm{EU} / \mathrm{mL}$ during SARA in dairy cows (Gozho et al., 2007; Emmanuel et al., 2008; Khafipour et al., 2009). However, we have observed ruminal concentrations of 250,000 to $350,000 \mathrm{EU} / \mathrm{mL}$ in some cows during SARA and we speculate that free rumen LPS concentration must be higher during acute rumen acidosis than during SARA. Whether the ruminal concentration of LPS was not high enough to disrupt the rumen barrier function during SARA and the accumulation of free LPS in the hindgut reached a level that impairs the intestinal barrier function during grain-induced SARA remains to be answered.

The initiation and magnitude of the acute phase response is coordinated by proinflammatory cytokines such as tumor necrosis factor- $\alpha$, IL-1, and IL-6 (Sriskandan and Altmann, 2008). Release of these mediators in response to plasma LPS reduces feed intake (Steiger et al., 1999). Plasma LPS also reduces the insulin sensitivity of the liver cells through the function of CD14, a cell membrane receptor of LPS, and increases blood glucose level (Cani et al., 2007). These changes can alter the direction of propionate metabolism in hepatocytes from gluconeogenesis to oxidation as acetyl CoA, which causes satiety (Allen, 2000). While confirming earlier results, these observations suggest that the differences in the DMI response between 2 models of SARA induction can be also in part due to the increased plasma LPS and proinflammatory mediators of acute phase response during grain-induced SARA (Khafipour et al., 2009).

\section{CONCLUSIONS}

A rumen $\mathrm{pH}$ depression typical of SARA (at least $180 \mathrm{~min} / \mathrm{d}$ of $\mathrm{pH}<5.6$ ) was created by increasing the dietary content of pelleted forage without changing the $\mathrm{F}: \mathrm{C}$ ratio and dietary starch content. This induction was accompanied by increases in rumen VFA, osmolality, and LPS that were similar to those observed during grain-induced SARA. Also, the induction of SARA in our study decreased milk yield and milk fat percentage and yield, similar to what has been observed during experimentally grain-induced SARA. However, in our study, the induction of low $\mathrm{pH}$ and high free LPS in the rumen was not accompanied by an inflammatory response, whereas grain-induced SARA commonly initiates such a response. Moreover, the induction of low $\mathrm{pH}$ or high LPS in the rumen in this study did not reduce DMI, which has been reported as one of the key symptoms of SARA. We speculate that high luminal concentrations of free LPS can disrupt the barrier function of the gut and cause translocation of free LPS into the blood circulation. However, free rumen LPS concentrations that are typical of SARA may not be high enough for this impairment of the barrier function. Inclusion of additional starch during grain-induced SARA may trigger the release of LPS from gram-negative bacteria in the lower gut and increase the free luminal LPS to levels that impair the barrier function of monolayer epithelium of the intestine, cause translocation of LPS, and initiate the inflammatory reaction that is seen during grain-induced SARA. The differences in the effects of the rumen $\mathrm{pH}$ depressions during alfalfa pellet-induced SARA and grain pellet-induced SARA challenge the 
current definition of SARA, which is only based on rumen $\mathrm{pH}$ depression.

\section{ACKNOWLEDGMENTS}

This study was supported by grants from Dairy Farmers of Canada (DFC), the Agri-Food Research Development Initiative (ARDI), and the Natural Sciences and Engineering Research Council of Canada (NSERC). The authors thank the staff of the Dairy Research Unit in Glenlea at the University of Manitoba, for maintenance and care of the animals, and technicians, graduate students, and postdoctoral fellows in the Department of Animal Science, University of Manitoba, for lab assistance and technical support during the experiment. Special thanks to Gary Crow from the Department of Animal Science at the University of Manitoba for his assistance with the statistical analyses.

\section{REFERENCES}

Allen, M. S. 2000. Effects of diet on short-term regulation of feed intake by lactating dairy cattle. J. Dairy Sci. 83:1598-1624.

AlZahal, O., E. Kebreab, J. France, M. Froetschel, and B. W. McBride. 2008. Ruminal temperature may aid in the detection of subacute ruminal acidosis. J. Dairy Sci. 91:202-207.

Andersen, P. H. 2000. Bovine endotoxicosis: Aspects of relevance to ruminal acidosis. Dr. Vet. Sci. Thesis. The Royal Veterinary and Agricultural University, Copenhagen, Denmark.

Andersen, P. H., and N. Jarlov. 1990. Investigation of the possible role of endotoxin, TXA2, PGI2 and PGE2 in experimentally induced rumen acidosis in cattle. Acta Vet. Scand. 31:27-38.

Anderson, S. D. 1984. Endotoxic and anaphylactic-type shock in steers from intravenous injection of Escherichia coli endotoxin and ruminal absorption of endotoxin. MSc Thesis. Kansas State University, Manhattan.

AOAC. 1990. Official Methods of Analysis. 15th ed. Association of Official Analytical Chemists, Arlington, VA.

Beauchemin, K. A., W. Z. Yang, and L. M. Rode. 2003. Effects of particle size of alfalfa-based dairy cow diets on chewing activity, ruminal fermentation, and milk production. J. Dairy Sci. 86:630643.

Bertok, L. 1998. Effect of bile acids on endotoxin in vitro and in vivo (physico-chemical defense): Bile deficiency and endotoxin translocation. Ann. N. Y. Acad. Sci. 851:408-410.

Bevans, D. W., K. A. Beauchemin, K. S. Schwartzkopf-Genswein, J. J. McKinnon, and T. A. McAllister. 2005. Effect of rapid or gradual grain adaptation on subacute acidosis and feed intake by feedlot cattle. J. Anim. Sci. 83:1116-1132.

Bhandari, S. K., K. H. Ominski, K. M. Wittenberg, and J. C. Plaizier. 2007. Effects of chop length of alfalfa and corn silage on milk production and rumen fermentation of dairy cows. J. Dairy Sci. 90:2355-2366.

Cani, P. D., J. Amar, M. A. Iglesias, M. Poggi, C. Knauf, D. Bastelica, A. M. Neyrinck, F. Fava, K. M. Tuohy, C. Chabo, A. Waget, E. Delmee, B. Cousin, T. Sulpice, B. Chamontin, J. Ferrieres, J. F. Tanti, G. R. Gibson, L. Casteilla, N. M. Delzenne, M. C. Alessi, and R. Burcelin. 2007. Metabolic endotoxemia initiates obesity and insulin resistance. Diabetes 56:1761-1772.

CCAC. 1993. Guide to the Care and Use of Experimental Animals. Vol. 1. 2nd ed. Canadian Council on Animal Care, Ottawa, ON, Canada.

Chin, A. C., A. N. Flynn, J. P. Fedwick, and A. G. Buret. 2006 The role of caspase-3 in lipopolysaccharide-mediated disruption of intestinal epithelial tight junctions. Can. J. Physiol. Pharmacol. 84:1043-1050.

Cooper, R. J., and T. J. Klopfenstein. 1996. Effects of rumensin and feed intake variation on ruminal pH. Pages A1- A14 in Update on Rumensin/Tylan/Micotyl for the Professional Feedlot Consultant. Elanco Animal Health, Greenfield, IN.

Daffaalla, B. F. M., and R. N. B. Kay. 1980. Effect of hay particle size on retention time, dry matter digestibility, and rumen $\mathrm{pH}$ in sheep. Proc. Nutr. Soc. 39:71A.

Duffield, T., J. C. Plaizier, A. Fairfield, R. Bagg, G. Vessie, P. Dick, J. Wilson, J. Aramini, and B. McBride. 2004. Comparison of techniques for measurement of rumen $\mathrm{pH}$ in lactating dairy cows. J. Dairy Sci. 87:59-66.

Emmanuel, D. G. V., S. M. Dunn, and B. N. Ametaj. 2008. Feeding high proportions of barley grain stimulates an inflammatory response in dairy cows. J. Dairy Sci. 91:606-614.

Emmanuel, D. G. V., K. L. Madsen, T. A. Churchill, S. M. Dunn, and B. N. Ametaj. 2007. Acidosis and lipopolysaccharide from Escherichia coli B:055 cause hyperpermeability of rumen and colon tissues. J. Dairy Sci. 90:5552-5557.

Garrett, E. F., M. N. Pereira, K. V. Nordlund, L. E. Armentano, W. J. Goodger, and G. R. Oetzel. 1999. Diagnostic methods for the detection of subacute ruminal acidosis in dairy cows. J. Dairy Sci. 82:1170-1178.

Giger-Reverdin, S. 2000. Characterisation of feedstuffs for ruminants using some physical parameters. Anim. Feed Sci. Technol. 86:5369.

Gozho, G. N., D. O. Krause, and J. C. Plaizier. 2006. Rumen lipopolysaccharide and inflammation during grain adaptation and subacute ruminal acidosis in steers. J. Dairy Sci. 89:4404-4413.

Gozho, G. N., D. O. Krause, and J. C. Plaizier. 2007. Ruminal lipopolysaccharide concentration and inflammatory response during grain-induced subacute ruminal acidosis in dairy cows. J. Dairy Sci. 90:856-866.

Gozho, G. N., J. C. Plaizier, D. O. Krause, A. D. Kennedy, and K. M. Wittenberg. 2005. Subacute ruminal acidosis induces ruminal lipopolysaccharide endotoxin release and triggers an inflammatory response. J. Dairy Sci. 88:1399-1403.

Graham, C., and N. L. Simmons. 2005. Functional organization of the bovine rumen epithelium. Am. J. Physiol. Regul. Integr. Comp. Physiol. 288:R173-R181.

Horadagoda, N. U., K. M. Knox, H. A. Gibbs, S. W. Reid, A. Horadagoda, S. E. Edwards, and P. D. Eckersall. 1999. Acute phase proteins in cattle: Discrimination between acute and chronic inflammation. Vet. Rec. 144:437-441.

Khafipour, E., D. O. Krause, and J. C. Plaizier. 2009. A grainbased subacute ruminal acidosis challenge causes translocation of lipopolysaccharide and triggers inflammation. J. Dairy Sci. 92:1060-1070.

Kleen, J. L., G. A. Hooijer, J. Rehage, and J. P. Noordhuizen. 2003. Subacute ruminal acidosis (SARA): A review. J. Vet. Med. A Physiol. Pathol. Clin. Med. 50:406-414.

Krause, K. M., and G. R. Oetzel. 2005. Inducing subacute ruminal acidosis in lactating dairy cows. J. Dairy Sci. 88:3633-3639.

Lassman, B. A. 1980. Release of endotoxin from rumen bacteria and endotoxin absorption from the rumen. M.Sc. Thesis. Kansas State University, Manhattan.

Leonardi, C., F. Giannico, and L. E. Armentano. 2005. Effect of water addition on selective consumption (sorting) of dry diets by dairy cattle. J. Dairy Sci. 88:1043-1049.

Li, S., N. Gakhar, D. O. Krause, K. Ominski, and J. C. Plaizier. 2008. Effect of alfalfa pellet and grain pellet-induced subacute ruminal acidosis on feed and water intake, milk production, and endotoxin in feces and rumen fluid. In Proc. Western Canadian Dairy Seminar. Red Deer, Alberta, Canada.

McAllister, T. A., H. D. Bae, G. A. Jones, and K. J. Cheng. 1994. Microbial attachment and feed digestion in the rumen. J. Anim. Sci. 72:3004-3018.

Nagaraja, T. G., and E. C. Titgemeyer. 2007. Ruminal acidosis in beef cattle: The current microbiological and nutritional outlook. J. Dairy Sci. 90(E Suppl.):E17-E38. 
Plaizier, J. C. 2004. Replacing chopped alfalfa hay with alfalfa silage in barley grain and alfalfa-based total mixed rations for lactating dairy cows. J. Dairy Sci. 87:2495-2505.

Plaizier, J. C., D. O. Krause, G. N. Gozho, and B. W. McBride. 2008. Subacute ruminal acidosis in dairy cows: The physiological causes, incidence and consequences. Vet. J. 176:21-31.

Poppi, D. P., B. W. Norton, D. J. Minson, and R. E. Hendricksen. 1980. The validity of the critical size theory for particles leaving the rumen. J. Agric. Sci. 94:275-280.

SAS. 2004. SAS/STAT Users Guide. Release 9.1.2. SAS Inst. Inc., Cary, NC.

Sriskandan, S., and D. M. Altmann. 2008. The immunology of sepsis. J. Pathol. 214:211-223.

Steiger, M., M. Senn, G. Altreuther, D. Werling, F. Sutter, M. Kreuzer, and W. Langhans. 1999. Effect of a prolonged low-dose lipopolysaccharide infusion on feed intake and metabolism in heifers. J. Anim. Sci. 77:2523-2532.
Stone, W. C. 1999. The effect of subclinical rumen acidosis on milk components. Pages 40-46 in Cornell Nutr. Conf. Feed Manu., Syracuse, NY. Cornell University, Ithaca, NY.

Tajima, K., R. I. Aminov, T. Nagamine, K. Ogata, M. Nakamura, H. Matsui, and Y. Benno. 1999. Rumen bacterial diversity as determined by sequence analysis of $16 \mathrm{~S}$ rDNA libraries. FEMS Microbiol. Ecol. 29:159-169.

Uden, P. 1988. The effect of grinding and pelleting hay on digestibility, fermentation rate, digesta passage and rumen and fecal particle size in cows. Anim. Feed Sci. Technol. 19:145-157.

Vreugdenhil, A. C., M. A. Dentener, A. M. Snoek, J. W. Greve, and W. A. Buurman. 1999. Lipopolysaccharide binding protein and serum amyloid-A secretion by human intestinal epithelial cells during the acute phase response. J. Immunol. 163:2792-2798.

Wells, J. E., and J. B. Russell. 1996. The effect of growth and starvation on the lysis of the ruminal cellulolytic bacterium Fibrobacter succinogenes. Appl. Environ. Microbiol. 62:1342-1346. 